\title{
TITLE:
}

\section{$<$ Note> Arbors and cuttings: New trials for Green Corridor Project at Bossou-Nimba}

\section{$\operatorname{AUTHOR}(\mathrm{S})$ :}

Ohashi, Gaku; Hasegawa, Ryo; Kourouma, Makan; Matsuzawa, Tetsuro

\section{CITATION:}

Ohashi, Gaku ... [et al]. < Note> Arbors and cuttings: New trials for Green Corridor Project at Bossou-Nimba. Pan Africa News 2008, 15(2): 20-23

\section{ISSUE DATE:}

2008-12

URL:

http://hdl.handle.net/2433/143496

RIGHT:

Copyright (C) Pan Africa News. 


\title{
$<$ NOTE $>$
}

\section{Arbors and cuttings: New trials for Green Corridor Project at Bossou-Nimba}

\author{
Gaku Ohashi ${ }^{1}$,Ryo Hasegawa ${ }^{2}$, \\ Makan Kourouma ${ }^{3}$ and Tetsuro Matsuzawa ${ }^{1}$ \\ 1. Primate Research Institute, Kyoto University \\ 2. Phytoculture Control Co., LTD. \\ 3. Institut de Recherche Environnementale de Bossou
}

Since 1976, wild chimpanzees have been studied at Bossou, Guinea, in West Africa ${ }^{1,2}$. The Bossou group itself is extremely endangered. Since the beginning of our study more than 30 years ago, no female chimpanzee immigration has been recorded, whereas all of the female chimpanzees born at Bossou disappeared around sexual maturation $^{3}$. As a result, the percentage of aged individuals is increasing in the group. To make matters worse, the number of Bossou chimpanzees suddenly decreased to 12 in 2003, due to an epidemic of respiratory disease ${ }^{4}$. For the group's survival, individual immigration from the nearest groups is essential.

About $10 \mathrm{~km}$ away from Bossou, at least one chimpanzee group lives in the Nimba Mountains ${ }^{5}$. In order to promote individual interchange between the Bossou and Nimba groups, we started in 1997 the "Green Corridor Project", which has involved planting trees along a $4 \mathrm{~km}$ long expanse of savanna area separating Bossou from Nimba ${ }^{6}$. Owing to this effort, we can see today small forest patches growing in this area ${ }^{7}$. 
During a decade, we have grown saplings in a tree nursery at Bossou, and transported them into the savanna. During transplantation, the environment around the saplings is drastically changed. The saplings are forced to receive strong sunshine in the savanna. For this reason, the saplings often died within a few days. To minimize damage caused by solar insolation, we started to make arbors in the savanna to protect young saplings. The arbors were constructed from natural materials, as local people do for their temporal ceremonies: we used bamboos as columns, leaf stalks of Raffia as beams, and palm leaves as roof. The roof allows the passage of water, whilst providing shade.

On September 2007, we constructed 3 arbors and transplanted 25 Uapaca heudelotti saplings under each of them (i.e., 75 saplings in total). One year later, we checked the condition of the Uapaca trees under the arbors. Whereas 13 trees were damaged by termites, the other 62 trees survived and thrived (82.7\%). Some trees grew to $3 \mathrm{~cm}$ in diameter and $130 \mathrm{~cm}$ in height (Fig. 1). The arbor itself was small, but it proved to be a useful approach for creating patches of forest in the center of the savanna, compared to direct transplantation without protection which was often challenging. We continued to construct arbors in 2008 after the first trial, and a total of 23 arbors are now protecting young trees against strong sunshine of the savanna.

In 2007, we tested another planting method using tree cuttings. When we checked fences around villages, we noticed that some sticks were sprouting. We identified the sticks used for fences in 3 villages, including Bossou, and checked which species had shoots. Our study led us to investigate 8,998 sticks; 176 sticks were found to have new buds or leaves (Table 1). We counted 579 sticks of Uapaca heudelotti, but they did not have any shoots. When we transported saplings from tree nursery into the savanna, Uapaca was one of the most successful ones ${ }^{7}$. However, the Uapaca may be unbefitting in the tree cutting method. On the other hand, fifty one out of the 176 sprouting sticks were Spondias cytherea. We collected 1,523 cuttings of Spondias cytherea from forest, and directly planted the cuttings around gallery forest and small forest patches in savanna. Only 3 weeks later, 891 out of the 1,523 (58.5\%) cuttings were found to have produced new shoots (Fig. 2). We

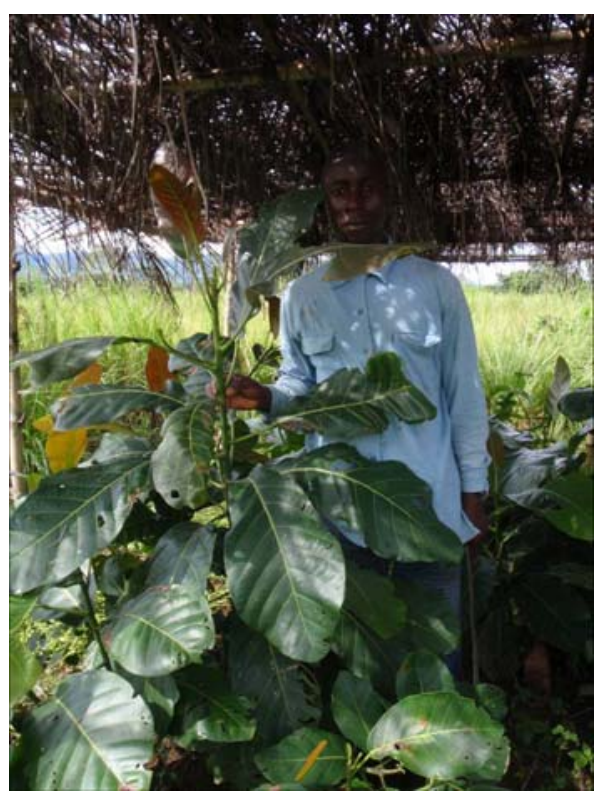

Fig. 1. Uapaca heudelotti trees under the arbor. They grew up to $130 \mathrm{~cm}$ in height.

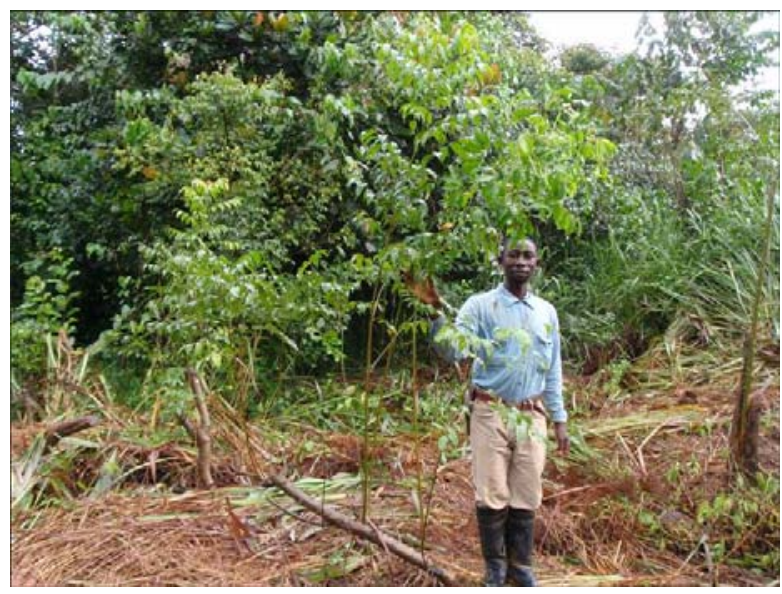

Fig. 2. Cutting of Spondias cytherea planted around patchy forest.

still need to monitor growth development of these tree cuttings over time, but this method may be useful for enlarging the forest patches adjoining the savanna.

These new attempts sparked great interest in the local people, because they consist of using techniques already familiar to them and applied to a conservation oriented reforestation project. Some villagers repaired the arbors voluntarily, while others started to plant cuttings including other species voluntarily. Changing savanna to forest by using the local methods is expected to increase environmental awareness of local communities and increasing their participation in conservation efforts. 
Table 1. Germination rate of cuttings. We identified the sticks used for fencing in three villages, including Bossou, and checked which species had produced shoots.

\begin{tabular}{|c|c|c|c|}
\hline Scientific name & $\begin{array}{l}\text { The number of sticks } \\
\text { used in fencing }\end{array}$ & $\begin{array}{l}\text { The number of } \\
\text { sprouting sticks }\end{array}$ & $\begin{array}{l}\text { Germination } \\
\text { rate }(\%)\end{array}$ \\
\hline "Kouyako" in local name & 41 & 29 & 70.7 \\
\hline Aspilia africana & 10 & 7 & 70.0 \\
\hline Spondias cytherea & 87 & 51 & 58.6 \\
\hline Spathodea campanulata & 16 & 8 & 50.0 \\
\hline Newbouldia laevis & 18 & 8 & 44.4 \\
\hline Dracaena perrottetiii & 16 & 7 & 43.8 \\
\hline Spondias mombin & 76 & 29 & 38.2 \\
\hline Nauclea latifolia & 105 & 8 & 7.6 \\
\hline Sterculia tragacantha & 20 & 1 & 5.0 \\
\hline Mareya micrantha & 57 & 2 & 3.5 \\
\hline Coffea arabica & 58 & 1 & 1.7 \\
\hline Craterispermum caudatum & 155 & 2 & 1.3 \\
\hline Craterispermum laurinum & 1,351 & 16 & 1.2 \\
\hline Albizia lebbeck & 17 & 0 & 0.0 \\
\hline Albizia sasa & 35 & 0 & 0.0 \\
\hline Albizia zygia & 8 & 0 & 0.0 \\
\hline Alchornea cordifolia & 1,049 & 0 & 0.0 \\
\hline Allophylus africanus & 21 & 0 & 0.0 \\
\hline Amphimas pterocarpoides & 13 & 0 & 0.0 \\
\hline Anthonotha macrophylla & 14 & 0 & 0.0 \\
\hline Blighia welwitschii & 9 & 0 & 0.0 \\
\hline Bridelia ferruginea & 57 & 0 & 0.0 \\
\hline Carapa procera & 124 & 0 & 0.0 \\
\hline Dichrostachys glomerata & 48 & 0 & 0.0 \\
\hline Elaeis guineensis (leaf stalks) & 1173 & 0 & 0.0 \\
\hline Ficus exasperata & 7 & 0 & 0.0 \\
\hline Ficus sur & 30 & 0 & 0.0 \\
\hline Funtumia elastica & 91 & 0 & 0.0 \\
\hline Harissonia abyssinica & 66 & 0 & 0.0 \\
\hline Harungana madagascariensis & 270 & 0 & 0.0 \\
\hline Lecaniodiscus cupanioides & 5 & 0 & 0.0 \\
\hline Macaranga hurifolia & 11 & 0 & 0.0 \\
\hline Manihot esculenta & 412 & 0 & 0.0 \\
\hline Morinda germinata & 24 & 0 & 0.0 \\
\hline Myrianthus libericus & 35 & 0 & 0.0 \\
\hline Phyllantus discoideus & 430 & 0 & 0.0 \\
\hline Phyllostachys sp. & 1,873 & 0 & 0.0 \\
\hline Premna hispida & 7 & 0 & 0.0 \\
\hline Pseudospondias microcarpa & 18 & 0 & 0.0 \\
\hline Raphia gracilis (leaf stalks) & 385 & 0 & 0.0 \\
\hline Terminalia glaucescens & 42 & 0 & 0.0 \\
\hline Terminalia superba & 8 & 0 & 0.0 \\
\hline Tetrorchidium didymostemon & 20 & 0 & 0.0 \\
\hline Uapaca heudelotti & 579 & 0 & 0.0 \\
\hline Vismia guineensis & 15 & 0 & 0.0 \\
\hline Others (28 species)* & 61 & 7 & 11.5 \\
\hline Unknown & 31 & 0 & 0.0 \\
\hline Total & 8,998 & 176 & 2.0 \\
\hline
\end{tabular}

* We compiled some species here, when the number of sticks was less than 5 .

Acknowledgements. This work was financially supported by MEXT-07102010, 12002009, and 16002001 and JSPS-HOPE to TM. The current project is supported by the Global Environment Research Fund (F-061) of the Ministry of the Environment, Japan to Dr. Toshisada Nishida. We thank the research assistants for promoting this project such as Boniface Zogbira, Paquille Cherif, Pascal Goumy, Jules Dore, and Henry
Gberegbe. Thanks are also due to the Guinean authorities, Drs. Kabine Kante and Tamba Tagbino from the DNRST. We are also grateful for the effort of colleagues who contributed this project during various stages; Drs. Yukimaru Sugiyama, Gen Yamakoshi, Tatyana Humle, and Nicolas Granier. 


\section{REFERENCES}

1 Matsuzawa T 2006. Bossou 30 years. Pan Afr News 13: 16-19.

2 Sugiyama Y, Koman J 1979. Social structure and dynamics of wild chimpanzees at Bossou, Guinea. Primates 20: 323-339.

3 Sugiyama Y 2004. Demographic parameters and life history of chimpanzees at Bossou, Guinea. Am J Phys Anthropol 124: 154-165.

4 Matsuzawa $\mathrm{T}$ 2006. Sociocognitive development in chimpanzees: a synthesis of laboratory work and fieldwork. In: Cognitive Development in Chimpanzees, Matsuzawa T, Tomonaga M, Tanaka M (eds), Springer, Tokyo, pp. 3-33.

5 Koops K, Matsuzawa $\mathrm{T}$ 2006. Hand clapping by a chimpanzee in the Nimba Mountains, Guinea, West Africa. Pan Afr News 13: 19-21.

6 Hirata S, Morimura N, Matsuzawa T 1998. Green passage plan (tree-planting project) and environmental education using documentary videos at Bossou: A progress report. Pan Afr News 5: 18-20.

7 Matsuzawa $\mathrm{T}$ 2007. Assessment of the planted trees in Green Corridor Project. Pan Afr News 14: 27-29. 